УДК 378.015.3:316.772.4]-057.875:61

DOI 10.11603/me.2414-5998.2020.1.10993

Yu. V. Lomakina ${ }^{1}$

ORCID https://orcid.org/0000-0002-8020-5254

ResearcherID D-5604-2017

R. Ye. Bulyk ${ }^{1}$

ORCID https://orcid.org/0000-0003-0651-534X

ResearcherID D-4122-2017

M. P. Tymofiieva ${ }^{1}$

ORCID https://orcid.org/0000-0003-3444-5182

ResearcherID B-4534-2017

L. Ya. Fedoniuk ${ }^{2}$

ORCID https://orcid.org/0000-0003-4910-6888

ResearcherID B-7985-2016

N. Ya. Muzyka ${ }^{1}$

ORCID https://orcid.org/0000-0002-3381-1163

ResearcherID D-2379-2017

${ }^{1}$ Higher State Educational Establishment of Ukraine

"Bukovinian State Medical University”, Chernivtsi

${ }^{2}$ I. Horbachevsky Ternopil National Medical University

\title{
A TECHNOLOGY OF COMMUNICATIVE COMPETENCE DEVELOPMENT OF FUTURE DOCTORS IN THE PROCESS OF PROFESSIONAL TRAINING
}

\author{
Ю. В. Ломакіна ${ }^{1}$, Р. Є. Булик ${ }^{1}$, М. П. Тимофієва ${ }^{1}$, Л. Я. Федонюк ${ }^{2}$, Н. Я. Музика ${ }^{1}$ \\ ${ }^{1}$ Вищий державний навчальний заклад України «Буковинський державний медичний \\ університет», Чернівці \\ ${ }^{2}$ Тернопільський національний медичний університет \\ імені І. Я. Горбачевського МОЗ України
}

\section{ТЕХНОЛОГІЯ РОЗВИТКУ КОМУНІКАТИВНОЇ КОМПЕТЕНТНОСТІ МАЙБУТНІХ ЛІКАРІВ У ПРОЦЕСІ ПРОФЕСІЙНОЇ ПІДГОТОВКИ}

\footnotetext{
Abstract. The article analyzed the problem of development of communicative competence of future doctors in the process of their professional training. The characteristic features of the physician communicative competent are distinguished.

As a result of research, a peculiarity of communicators is highlighted. A slight percentage of the surveyed have quite significant personal problems that require long-term psychotherapeutic work, that should precede measures directly aimed to the development of their communicative competence.

Models of communicative competence development are considered. It is presented a fairly a common feature, namely: competence in communication is understood as a result of quantitative accumulation of communication skills. It is assumed that at some point this number translates the person to a qualitatively new level of communicative behavior. Communicative skills are regarded as means of overcoming the drama of communication.

The meaning of the training in the context of professional training of specialists are emphasized and substantiated.

The basic training of communicative competence should be focused on developing the skills of active listening and regulation of emotional tension, since these skills allow to greatly solve the drama of communication.

The logic scheme of the training is proposed based on the fact that the professional communication of a doctor is considered as a sequence of communication tasks of varying degrees of complexity. The task of the training was to correct the settings of participants regarding communication with people in general and patients in particular; development of abilities to action in unusual situations, forecasting the consequences of people's interaction. In accordance with these tasks, a meaningful group operation is highlighted.
}

(C) Yu. V. Lomakina, R. Ye. Bulyk, M. P. Tymofiieva et al. 
The implementation of the program included the use of various psychotechnical methods of work: exercises, rehearsal of behavior, situational and role-playing games, group discussions and discussions, bodily and motor techniques.

Key words: communicative competence; dramas of communication; doctor; professional preparation; training.

Анотація. У статті аналізується проблема розвитку комунікативної компетентності майбутніх лікарів у процесі їх професійної підготовки. Виділено характерні риси комунікативно компетентного лікаря.

У результаті дослідження виділено особливість комунікаторів. Незначний відсоток досліджуваних має досить суттєві особистісні проблеми, які потребують тривалої психотерапевтичної роботи, що повинна передувати заходам, безпосередньо спрямованим на розвиток їхньої комунікативної компетентності.

Розглянуті моделі розвитку комунікативної компетентності. Представлена досить поширена спільна риса, а саме: компетентність у спілкуванні розуміється як результат кількісного накопичення комунікативних навичок. Передбачається, що у якийсь момент ця кількість переводить особистість на якісно новий рівень комунікативної поведінки. Комунікативні вміння розглядаються як засоби подолання драми спілкування.

Підкреслюється та обгрунтовується значення тренінгу у контексті завдань професійної підготовки фахівців. У базовому тренінгу комунікативної компетентності варто зосередитися на розвитку вмінь активного слухання та регуляції емоційної напруги, оскільки дані вміння дозволяють значною мірою вирішити драми спілкування.

Запропонована структурно-логічна схема побудови тренінгової роботи грунтується на тому, що професійне спілкування лікаря розглядається як послідовність комунікативних завдань різного ступеня складності. Завданням тренінгу була корекція установок учасників стосовно спілкування з людьми взагалі та пацієнтами зокрема; розвиток здатностей до дій у нестандартних ситуаціях, прогнозування наслідків взаємодії людей. Відповідно до цих завдань виділені змістовні блоки групової роботи.

Реалізація програми передбачала використання різноманітних психотехнічних прийомів роботи: вправ, репетиції поведінки, ситуаційно-рольових ігор, групових обговорень і дискусій, тілесно-рухових технік.

Ключові слова: комунікативна компетентність; драми спілкування; лікар; професійна підготовка; тренінг.

Introduction. In the most general view the communicative competence of a doctor can be described as a maturity of interpersonal and professional experience of interaction with others which the individual needs for successful functioning in both professional and public fields. Therefore, the communicative competence depends not only on individual traits of a person but on changes which take place in society (in health care system in particular) and on affected social mobility of a medical worker himself, as a result of those changes. Communicative competence of a doctor also predicts the presence of doctor's professional views and beliefs as well as emotionally positive attitude towards the patient regardless of his personal qualities and the whole range of communicative skills a doctor may need for medical interaction (formation of therapeutic alliance with a patient).

The aim - to study theoretically and methodologically the features of communicative competence of a doctor; to produce structurally logical scheme of training array of work with doctors.

Theoretical framework. The habits of a communicatively qualified doctor who correlates with a psychological effect of treatment are:

- a positive direction of interactions and absence of disregard reactions;

- a high level of empathy and self-esteem;

- an attitude to another person as to the value and an active party of the interaction.
The communicative competence of a doctor, which according to $\mathrm{S}$. A. Leager lies at the core of therapeutic alliance establishment with a patient allows:

- better to identify and react to verbal and non-verbal signs of patients;

- more effectively conduct diagnostics as an effective diagnostic depends not only on finding of the corporal symptoms of a disease but also on an ability of a doctor to identify somatic symptoms which may have psychological or social nature which in turn requires different plans of treatment;

- to demand a patient's approval of a treatment plan because the studies showed that communicative skills training affect patient's consent to take a prescribed medicine. A reluctance to hold to the prescribed cure is described as the most serious problem in the health care;

- to give the patients an adequate medical information and persuade them with reason about the advantages of healthy life style, thus increasing the role of a doctor in strengthening of health and prevention of illnesses;

- to influence on various forms of disease mapping (emotional, intellectual, motivational) and activate compensatory mechanism, enhance a psychosomatic potential of a patient's personality, help him to renew a connection with a world, to overcome so called adopted or learnt helplessness, to ruin stereotypes formed by a disease and create patterns of healthy reacting;

- doctors should act more effectively in particularly delicate situations of mutual relations "doctor-patient", 
for example when it is necessary to inform a patient that he is incurably sick or to tell to patient's relatives that he might die etc [2].

The examination of state of preparedness of future doctors for a qualified professional communication has shown that it is on a very low level. The overall picture proves that the most of the examined contingent have a tendency to build distant, high profile, "vertically" oriented relations with people, as well as a lack of communication skills that would aim at understanding, providing of support and would fulfil psychotherapeutic functions. At the same time, it should be mentioned that the contingent of future doctors is very inhomogeneous in its structure in the aspect of readiness to qualified communication, and there are substantial individual differences.

This way a part of students - future doctors, first of all needs help in development of corresponding crafts and skills which could provide a formation of mutual relations with patients and colleagues. These students generally have positive arrangements for communication with other people; they also have necessary personal features.

The significant part of the examined, as data of our study proves, apart from the development of communicative crafts and skills needs psychotherapeutic and advisory help aimed at alteration of arrangements and personal position in communication, correction of self-perception and self-relation.

A small percentage of the examined have essential personal problems that need a continuous psychotherapeutic work which must take place prior to the activities directly aimed at their communicative competence development.

An analysis of literature sources on the issue of a development of ability to a qualified communication showed the presence of both common and distinguishing traits in a vision of patterns of communicative competence formation.

Practically all authors consider a group training to be a basic form of a successful development of communicative competence O. V. Evtykhov, V. G. Romek, Yu.V. Suchovershina and others [1, 4, 6-9]. Along with it they specify that namely group form of work creates conditions for obtaining personal experience in communication by members of the group in the situations of interpersonal interaction, gives a chance to provide and receive feedback, to challenge and solve personal problems of the members which may hinder an effective communication etc.

The value of training in the context of tasks of professional preparation of specialists is emphasized particularly. It is specifically stressed by L. A. Petrovskaya, who says that an opportunity to work directly with experience allows the use of psychological training as an important element of psychological preparation [3]. This moment is important for us from the point of view of the tasks of our examination.

According to many authors favorable conditions are created in the training for direct and urgent comparison of present information about communication and communicative activity itself, emotional living of new models of behavior and results connected with them, which are provided by a feedback.

A specialist who undergoes a preparation in training, getting a feedback, stresses $\mathrm{O}$. V. Evtykhov, discovers deficiencies of crafts and skills he has, as well as gaps in theoretical knowledge and inappropriateness of arrangements and stereotypes.

Summing up the models of communicative competence development dissected above it should be mentioned that a prevalent common feature is presented here, namely; a competence in communication is understood as a result of a quantitative accumulation of communicative skills. It is expected that at some point this quantity brings an individual to a qualitatively new level of communicative behavior. Such view can be spotted at many native and foreign authors.

O. V. Sydorenko proposes an original approach in understanding a communicative competence itself and conditions of its development. As a universal unit she reviews "communication drama" [5]. According to O. V. Sydorenko one needs communicative skills to overcome those dramas of communication on the highest possible level. Unlike many other authors, O. V. Sydorenko highlights the task as a fundamental point in the development of communicative competence of a personality. She believes that logic of development of communicative competence must be seen within the aspect of ever more difficult assignment solving, interactions and mutual influences. O. V. Sydorenko underscores that "the communication drama approach" is not as scientific as it is practical. She deems it allows technologizing more distinctly a process of communicative competence of personality using training procedures. After O. V. Sydorenko "communication drama" is a difficult task that needs to be solved, it's a "challenge”, one needs to cope with. In this context communicative crafts are seen by her as ways of overcoming a drama of communication. All in all, the author highlights dramas of communication: drama of listening, drama of comprehension, drama of 
action and drama of self-expression. The gist of these dramas can briefly be formulated as follows:

- Drama of listening - listen but don't hear;

- Drama of comprehension - hear but don't understand;

- Drama of action - understand but not able to do;

- Drama of self-expression - able to do myself but cannot formulate how to do.

Based on this, the task of development of corresponding skills is set, which will allow beating the named above dramas of communication. O. V. Sydorenko thinks that in basic training of communicative competence it is worth focusing on elaborating of skills of active listening and regulation of emotional tension as these skills allow to a greater extent solve mentioned above dramas of communication. With that the author recognizes that the repertory of crafts does not dry up with named skills necessary for a qualified communication in various situations of interpersonal interaction. Specialized trainings suggest developing an ability to act and display own thoughts and feelings, for instance self-presentation, negotiations, influence etc.

A program of development of communicative competence of future doctors was built on the basics of training technologies on both general readiness of participants of the sessions to qualified communication, and taking into consideration the presence of fundamental individual differences in personal and communicative indicators among them.

The first task to solve in the training was a correction of arrangements of the participants in conversation with people at all and patients in particular. The solution of this task foresaw a reflection of present arrangements of training participants and formation in them the arrangements to comprehensive and directive communication and positive perception of oneself and others and laying down partner relations with them.

The second task of work with the group participants was the adjustment of basic communicative crafts and skills, without mastering which any effective communication is impossible. We are talking about skills of listening and speaking as well as setting of a psychological contact with a partner.

Solution of the third task involved a development in young doctors an ability for qualified communication in typical situations of interaction with patients. Such situations include the first encounter with a patient, a collection of information of medical history, conversations with the family of a patient, having interviews aimed at preventing the disease, granting psychological support to a patient or members of his family etc.
A successful solution of the first three tasks creates preconditions for setting a fourth task - a development of the ability to actions in extraordinary situations, prediction of consequences of interaction between people, holding of psychological consulting of patients and members of their families.

There were defined three main tasks of work with the group: correction and development of arrangements of participants for communication, partners and themselves; mastering of basic communicative skills; development of an ability to solve communicative tasks.

According to these tasks, one can distinguish informative blocks of group work:

- self-investigation of group participants aimed at revealing of existing arrangements of communication with others, assimilation of rules and principles of comprehensive and directive communication, realization of features of collaborative interrelations;

- development of basic skills of professional communication: a skill to listen actively, a skill to use verbal and non-verbal means of transmitting of information, a skill to organize and support dialogue, a skill to understand an emotional state of partners in communication.

A development of an ability to solve typical situations of interaction with partners, which repeat constantly in the doctoral practice: situations of first encounter and meeting of a patient, setting of a psychological contact; holding of interviews with patients and members of their families; organization and holding of meetings with families of the patients to include them into the process of treatment as doctor's aides; conducting of preventive interviews with various categories of patients; development of an ability adequately to solve irregular situations of communication with patients, to predict ramifications of interaction and the behavior of subjects of communication, a skill to provide psychological help to patients and members of their families, mastering of basics in consulting and psychotherapy.

Solving of tasks of development of communicative competence of future doctors was accomplished in training form as the most adequate to a set aim. An implementation of program forecast to use of different psychotechnical techniques in work: exercises, rehearsals of behavior, situational-role games, group speculations and discussions corporally-motional technique and so on. Before the beginning and after the end of training session's cycle we applied diagnostic procedures which targeted the evaluation of dynamics 
of development level of communicative features of participants. It gave us a chance to define personal achievements of group members and therefrom to establish the effectiveness of sessions. The duration of training (of one full cycle) was 24 hours which were distributed on three parts eight hours each, according to courses of work. The sessions were held by the following mode: 4 hours (one session) once a week. The full cycle of training is advisable to repeat not less than once a year, gradually making the tasks for the participants more difficult.

Every participant under nine parameters defined effectiveness of implementation of suggested program:

- an ability to attentively listen to the partner in communication;

- to pay thorough attention to non-verbal displays of partners;

- to transmit the gist of what was heard with one's own words without contortions of the content (rehash);

- to highlight the core in what was heard and to sum up what was said;

- to make specifying remarks which help partners better realize their own thoughts and feelings;

- to ask specifying questions aimed at better understanding of partner in communication;

- to set and support a psychological contact with a partner;

- to support partners in the right moment so that the alleviating effect could be felt;

- to understand an inner world of other person and transmit this to a partner so that he could sense that he is understood.

A procedure of an estimation of mentioned features included standardized written questioning (self and mutual estimation) and observation under appropriate scheme. Received data proves that at the beginning of sessions more than half of the participants had low and very low level of development of communicative features. Most underdeveloped were an ability to provide support to the partners, understand them and an ability to explain the content of what was said and highlight the key point.

Thus, every fifth participant of the training had a very low level of communicative readiness, the third of the participants had low level and another third had average level. The above average level of readiness can be verified only at one out of ten participants of the training, and the high level is absent at all.

The diagnostics, held under same methodology showed presence of positive changes in the level of communicative readiness of participants. The number of participants with low and very low levels of readiness shrank (overall down to $30 \%$ against $52 \%$ before the start of the work of the group). The quantity of participants with an average and above average levels of readiness increased up to two thirds.

Conclusions and Prospects for Research. The approbation of the training of communicative readiness development of future doctors built on the foundations of task approach showed its effectiveness as a work technology with medical students and beginner doctors. Conducting of one full cycle of training sessions allows to increase significantly the readiness of future doctors to professional communication with patients, however to ensure a long-term effect it is worth conducting such sessions periodically, expanding and deepening a range of problems which are worked upon at the training.

A logic of structure of training sessions can be imagined as parallel buildup of two interrelated directions of work. On the one hand it is a formation of arrangements, communicative crafts and skills, first of all skills of listening and attentive behavior, on the other it is a development of an ability to apply acquired communicative skills for the solving of dramas of communication.

One of the main conditions of implementing of training technologies of communicative competence of future doctors we consider a recognition of communicative readiness as crucial part of professional preparedness of a doctor.

In prospect, it is worth continuing to teach students different techniques of communication. The study of effectiveness of implementing of innovative technologies ("portfolio", audio and video recordings) in practical preparation of future doctors will help to unleash a personal approach to education bringing the process of teaching closer at most to real conditions of professional activity that develop professional and communicative competence.

\section{List of literature}

1. Евтихов О. В. Практика психологического тренинга / О. В. Евтихов. - СПб. : Речь, 2004. - 256 с.

2. Лигер С. А. Формирование копинг-поведения студентов медицинского вуза и его влияние на личностно- професиональное развитие врача : дисс. ... канд. психол. наук: 19.00.04 / С. А. Лигер. - М.,1997. - 191 с.

3. Петровская Л. А. Развитие компетентного общения как одно из направлений оказания психологической 
помощи / Л. А. Петровская // Введение в практическую социальную психологию / под ред. Ю. М. Жукова, Л. А. Петровской, О. В. Соловьевой. - М. : Смысл, 1996. - С. 150-167.

4. Ромек В. Г. Тренинг уверенности в межличностных отношениях / В. Г. Ромек. - СПб. : Речь, 2003. - 175 с.

5. Сидоренко Е. В. Тренинг коммуникативной компетентности в деловом взаимодействии / Е. В. Сидоренко. - СПб. : Речь, 2004. - 208 с.

6. Суховершина Ю. В. Тренинг коммуникативной компетенции / Ю. В. Суховершина, Е. П. Тихомирова, Ю. Е. Скоромная. - М. : Акад. проект; Трикста, 2006. - 112 с.

7. Тюріна В. Професійна компетентність як фактор формування конкурентоспроможності майбутніх фа-

\section{References}

1. Evtykhov, O.V. (2004). Praktika psihologicheskogo treninga [Psychological training practice]. Saint-Petersburg: Rech [in Russian].

2. Liger, S.A. (1997). Formirovanie koping-povedeniya studentov meditsinskogo VUZa i ego vliyanie na lichnostnoprofesionalnoe razvitie vracha [Formation of medical university students coping behavior and its influence on the personal and professional development of the doctor]. Candidate's thesis [in Russian].

3. Petrovskaya, L.A. (1996). Razvitie kompetentnogo obshcheniya kak odno iz napravleniy okazaniya psihologicheskoy pomoshchi. Vvedenie v prakticheskuyu sotsialnuyu psihologiyu [Development of competent communication as one of the directions of rendering psychological help. Introduction to practical social psychology]. Moscow: Smysl [in Russian].

4. Romek, V.G.(2003). Trening uverennosti vmezhlichnostnykh otnosheniyakh [Confidence training in interpersonal relationships]. Saint-Petersburg: Rech [in Russian].

5. Sydorenko, E.V. (2004). Trening kommunikativnoy kompetentnosti $v$ delovom vzaimodeystvii [Communicative competence training in business interaction]. SaintPetersburg: Rech [in Russian]. хівців / В. Тюріна, Л. Пляка // Молодіжна політика: проблеми і перспективи : зб. матеріалів VI Міжнар. наук.-практ. конф., 15-16 травня 2009 р. - Дрогобич, 2009. - C. 135-137.

8. Vorwerg C. Communicative competence: linguistic aspects. In: International encyclopedia of the social and behavioral sciences. Amsterdam (The Netherlands): Elsevier; 2015: 294-301. Access mode : https://doi. org/10.1016/B978-0-08-097086-8.53042-6.

9. Zhura V. Developing communicative competence in students of higher medical schools: mini-review article / V. Zhura, J. Rudova // Medical University. - 2019. - Vol. 2 (1). - Access mode : https://www.researchgate.net/publication/332242928. DOI: http://dx.doi.org/10.2478/medu-2019-0001.

6. Sukhovershina, Yu.V., Tihomirova, E.P., \& Skoromnaya, Yu.E. (2006). Trening kommunikativnoy kompetentsii. [Communicative competence training]. Moscow: Akad. Proekt; Triksta [in Russian].

7. Tiurina, V., \& Pliaka, L. (2009). Profesiina kompetentnist yak faktor formuvannia konkurentospromozhnosti maibutnikh fakhivtsiv [Professional competence as a factor of future specialists competitiveness formation]. Molodizhna polityka: problemy i perspektyvy. Zbirnyk materialiv VI Mizhnarodnoyi naukovoprakt. konf. - Youth Policy: Problems and Prospects. Collection of the Materials of VI International Scientific and Practical Conference. May 15-16. Drohobych [in Ukrainian].

8. Vorwerg, C. (2015). Communicative competence: linguistic aspects. In: International encyclopedia of the social and behavioral sciences. Amsterdam (The Netherlands): Elsevier. Retrieved from: https://doi. org/10.1016/B978-0-08-097086-8.53042-6.

9. Zhura, V., \& Rudova, J. Developing communicative competence in students of higher medical schools. Minireview article. Medical University, 2(1). 2019. Retrieved from: https:/www.researchgate.net/publication/332242928. DOI: http://dx.doi.org/10.2478/medu-2019-0001. 